\title{
Large calcite and bulk-rock volume loss in metacarbonate xenoliths from the Quérigut massif (French Pyrenees)
}

\author{
Cyril Durand · Didier Marquer · Lukas Baumgartner • \\ Philippe Goncalves · Philippe Boulvais · Michel Rossy
}

Received: 8 October 2007 / Accepted: 30 October 2008/Published online: 20 December 2008

(C) Springer-Verlag 2008

\begin{abstract}
Chemical mass transfer was quantified in a metacarbonate xenolith enclosed within the granodiorite of the Quérigut massif (Pyrenees, France). Mass balance calculations suggest a strong decrease of $\mathrm{CaO}, \mathrm{SrO}$ and $\mathrm{CO}_{2}$ contents (up to $-90 \%$ ), correlated with a decrease of modal calcite content as the contact is approached. Most other chemical elements behave immobile during metasomatism. They are therefore passively enriched. Only a small increase of $\mathrm{SiO}_{2}, \mathrm{Al}_{2} \mathrm{O}_{3}$ and $\mathrm{Fe}_{2} \mathrm{O}_{3}$ contents occurs in the immediate vicinity of the contact. Hence, in this study, skarn formation is characterized by the lack of large chemical element influx from the granitoid protolith. A large decrease of the initial carbonate volume (up to $-86 \%$ ) resulted from a combination of decarbonation reactions and loss of $\mathrm{CaO}$ and $\mathrm{CO}_{2}$. The resulting volume change has potentially important consequences for the interpretation of stable isotope profiles: the isotope alteration could have occured over greater distances than those observed today.
\end{abstract}

Communicated by J. L. R. Touret.

C. Durand $(\bowtie) \cdot$ L. Baumgartner

Insitute of Mineralogy and Geochemistry,

University of Lausanne, BFSH2,

1015 Lausanne, Switzerland

e-mail: cyril.durand@unil.ch

D. Marquer · P. Goncalves · M. Rossy

Chrono-Environment, UMR 6249,

University of Franche-Comté, 16 Route De Gray,

25030 Besançon Cedex, France

P. Boulvais

Geosciences, UMR 6118, University Rennes 1,

Campus de Beaulieu, 35042 Rennes Cedex, France
Keywords Mass transfer - Contact metamorphism . Skarn · Calcite loss · Volume loss · Decarbonation . Stable isotope

\section{Introduction}

Skarn formation is due to metasomatism. This change in the chemical rock composition is often linked to the interaction with fluids. Numerous studies have dealt with the role of chemically reactive fluid flow associated with mineralogical, isotopic and others chemical changes (Forester and Taylor 1977; Taylor and O'Neil 1977; Nabelek et al. 1984; Ferry 1991, 1994; Cartwright et al. 1997; Ferry et al. 1998, 2002; Buick and Cartwright 2000; Cartwright and Buick 2000; Cook and Bowman 2000; Buick and Cartwright 2002). Processes of diffusion (e.g. Taylor and O'Neil 1977; Nagy and Parmentier 1982; Cartwright and Valley 1991) and advection (e.g. Rumble et al. 1982; Dipple and Ferry 1992; Nabelek and Labotka 1993; Ferry 1994; Gerdes and Valley 1994; Cook et al. 1997; Roselle et al. 1999; Ferry et al. 2002) have been invoked to explain mass transfer in such environments. Mass transfer studies have addressed skarn formation and related ore deposits (Einaudi and Burt 1982; Harris and Einaudi 1982; Brown and Essene 1985). Mass transfer from intrusive rocks into metasedimentary rocks are generally called upon to explain element changes during contact metamorphism (Ferry 1982; Brown and Essene 1985; van Marcke de Lummen and Verkaeren 1986; Gieré 1990; Nabelek and Labotka 1993; Gerdes and Valley 1994; Buick and Cartwright 2002; Abu El-Enen et al. 2004). However, the reverse process is also conceivable: removal of elements from the metasedimentary rocks, as proposed, for example, by Tracy et al. (1983) and Ague (2003) during regional metamorphism. 
In this study, we focus on the understanding of chemical mass transfer inside a metacarbonate xenolith. Mass-balance calculations indicate that element changes are due to an element loss which results in a large volume loss. This has implications for the interpretation of the isotope alteration fronts.

\section{Geological setting}

The Quérigut granitoid massif is one of the late Hercynian calc-alkaline granitoid complexes within the Axial Zone (Barnolas and Chiron 1996; Debon et al. 1996; Guitard et al. 1996) of the Eastern part of the French Pyrénées (Fig. 1). It was dated at $307 \pm 2 \mathrm{Ma}$ by Roberts et al. (2000). This composite magmatic complex shows a concentric petrographic zonation. It is divided into four igneous units (Leterrier 1972; Marre 1973; Roberts et al. 2000; Durand et al. 2006). It consists of (1) a central biotite-muscovite-bearing monzogranite unit; (2) surrounded by a biotite-bearing monzogranite unit; (3) a biotitehornblende-bearing granodiorite unit which is only present in the southern margin of the Massif and (4) meter to hectometre scale mafic and ultramafic lenses of gabbrodiorite, amphibolite and cortlandite occurring only in the two outermost units. This magmatic complex intruded a deformed Palaeozoic metasedimentary sequence consisting of metapelites and metacarbonates (Leterrier 1972; Marre 1973; Aparicio 1975; Toulhoat 1982; Takeno 1994; Aubry 1999; Monnot 1999). Metapelites in contact with the

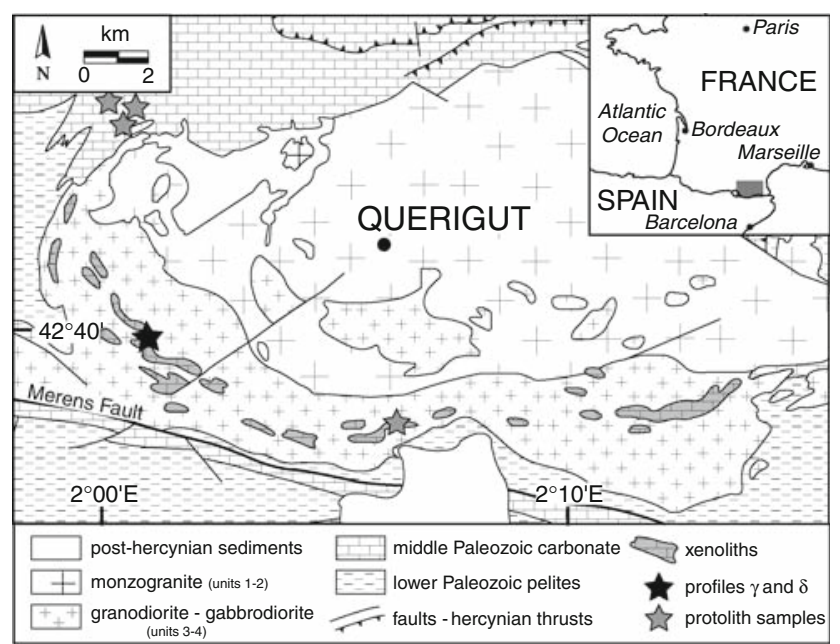

Fig. 1 Simplified geological map of the Quérigut region in the Eastern Pyrenees, France (after Durand et al. 2006). Metacarbonate xenoliths (in grey) are localized in the South-Western part of the Quérigut complex, inside the biotite-hornblende-bearing granodiorite unit. The location of the profile is given by the black star. Locations of samples used to define the carbonate protolith are given by grey stars granitoids developed the low-pressure metamorphic assemblage andalusite $+\mathrm{K}$-feldspar. This was used to constrain the $P T$ conditions in the contact aureole at 500$650^{\circ} \mathrm{C}$ and 0.2-0.27 GPa (Leterrier 1972; Takeno 1994; Monnot 1999; Roberts et al. 2000). Paleozoic carbonates occur either as host rocks or as decametre thick, up to hundreds of meter long xenoliths. They are fully enclosed within the intrusive magmatic rocks (Fig. 1). They are aligned in the sub-vertical igneous, syn-magmatic deformation (Marre 1973; Durand et al. 2006).

\section{Mineralogical evolution in metacarbonate xenoliths}

Metacarbonates were sampled along two profiles at Laurenti, named $\delta$ and $\gamma$. The profiles were horizontally collected, perpendicular to the intrusive contacts (Fig. 2). Both profiles are located in the same xenolith. Profile $\delta$ was collected towards the main diorite contact, whereas profile $\gamma$ is adjacent to a metre-thick granitic dyke which crosscuts the metacarbonates. Both profiles share the same starting samples M40 and M41 (black circles, Fig. 2). Plutonic rocks were also sampled to constrain fluid circulations during the contact metamorphic event using $\mathrm{O}$ and C stable isotopes (Durand et al. 2006).

Details on the mineralogical evolution in metacarbonate profiles are given in Durand et al. (2006). Salient features of the mineralogical evolution, from the core of the xenolith to the exoskarn, are summarized below. Samples from the xenolith core are essentially calcitic rich marbles with modal amounts of calcite greater than 90\%. They contain minor amounts of metamorphic minerals (amphibole, anorthite, K-feldspar, biotite, quartz). The metacarbonates are only thermally affected by the intrusion and chemically represent the initial protolith. At about $100 \mathrm{~cm}$ dramatically. These decreases coincide with the appearance of clinopyroxene, followed by garnet, wollastonite, and clinozoisite to form a thin, massive exoskarn zone (some millimetres to centimetres). The presence of wollastonite in the exoskarn implies a $\mathrm{H}_{2} \mathrm{O}$-rich fluid or very high temperatures (Spear 1995).

\section{Analytic procedure}

Bulk rock analyses were obtained by XRF with a Philips PW2400 XRF spectrometer at the University of Lausanne, Switzerland. Total iron is given as $\mathrm{Fe}_{2} \mathrm{O}_{3}$. The $\mathrm{CO}_{2}$ content of the samples was measured by coulometry on a JUWE Coulomat 702 (University of Lausanne, Switzerland). Reference material Merck 2060 (suprapur $\mathrm{CaCO}_{3}$ ) yielded a $\mathrm{CO}_{2}$ value of $44.8 \pm 1.0 \%(n=20)$, close to the theoretical value of $\mathrm{CO}_{2}$ in pure $\mathrm{CaCO}_{3}$ of $43.97 \%$. Water 
Fig. 2 Schematic cross-section of the studied metacarbonate xenolith. It is enclosed in a granodioritic intrusion and crosscut by a metre-scale dyke of granite. The sample locations for profiles $\gamma$ (squares) and $\delta$ (stars) are given. Open symbols are used for the igneous rock samples, filled symbols are used for the carbonate samples. Note that an asymmetric skarn develop. Endoskarns are larger than exoskarns

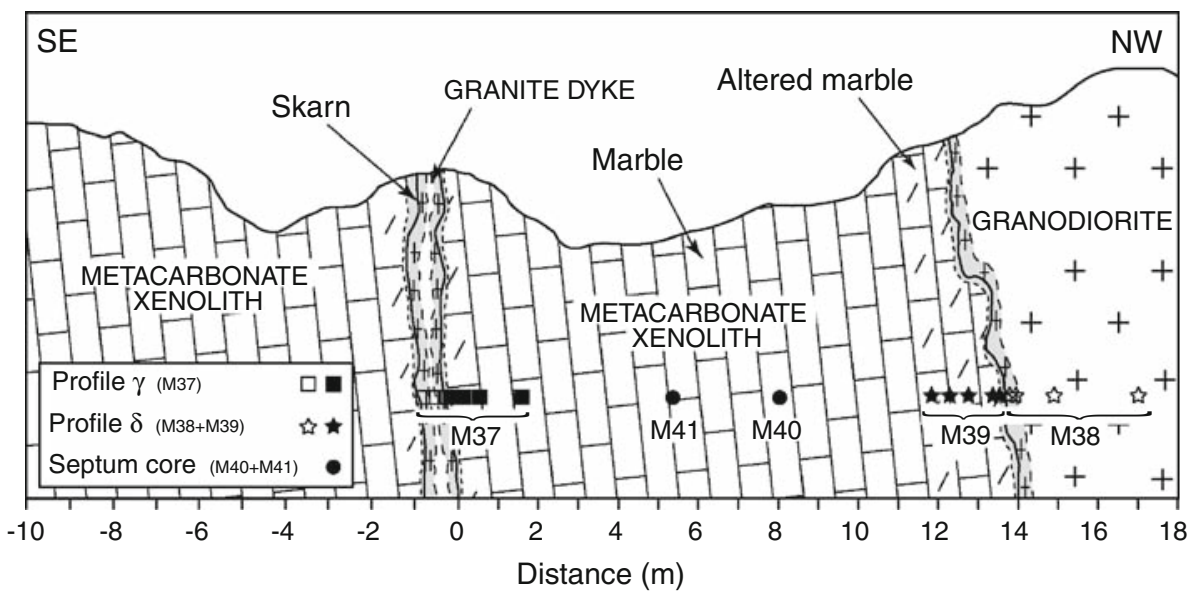

porosity measurements were performed at the University of Franche-Comté, France, to quantify the total porosity $\left(\phi_{\mathrm{t}}\right)$ and the density of the samples. These measurements were performed on small rock samples which we subsequently used for the thin section preparation. The samples were dried at $60^{\circ} \mathrm{C}$, degassed during $24 \mathrm{~h}$ in an airtight enclosure and imbibed by degassed distilled water, under a dynamic vacuum. The total porosity, expressed in percentage, is given by:

$\phi_{\mathrm{t}}=\frac{W_{2}-W_{\mathrm{d}}}{W_{2}-W_{1}} \times 100$

where $W_{1}$ is the hydrostatic weight of the sample, $W_{2}$ the weight of the sample totally imbibed by water and $W_{\mathrm{d}}$ is the dry weight of the sample.

\section{Chemical mass transfers}

Bulk rock chemistry, calcite abundance and density are listed in Table 1. Figure 3 presents the evolution of $\mathrm{SiO}_{2}$ and $\mathrm{CO}_{2}$ contents versus $\mathrm{CaO}$ contents for both profiles. Also given are samples from other metacarbonate xenoliths in the Quérigut massif. The content of $\mathrm{CaO}$ and $\mathrm{CO}_{2}$ steadily decreases towards the contact with the intrusive rock, while the $\mathrm{SiO}_{2}$ content increases. This implies selective chemical mass transfer during contact metamorphism.

\section{Mass balance calculation}

Numerous mass balance approaches have been developed during the last decades to estimate chemical mass transfers and volume changes (Gresens 1967; Grant 1986; Brimhall and Dietrich 1987; Potdevin and Marquer 1987; Ague 1994; Baumgartner and Olsen 1995). Chemical mass transfers are basically quantified by comparing chemical composition of an unaltered rock (protolith) with altered rocks. It is important to accurately define the protolith composition. In this study, the carbonate protolith composition was calculated by averaging nine unaffected carbonate rocks from xenoliths and host rocks from the northern and south-western parts of the Quérigut massif. They consist of calcitic marbles with calcite contents above $90 \%$, close to the chemical composition of the studied xenolith core. They were sampled far from contact zones with intrusive rocks (from two metres to hundreds of metre) and are apparently unaffected by metasomatism.

Immobile chemical elements or volume changes need to be identified in order to establish the effective mass balance (Fig. 4). For example, for the same initial rock composition (25\% by volume of element $x$ and $75 \%$ by volume of element $y$ ), Fig. 4 shows that it is possible to obtain the same final rock composition by two opposite mass transfer scenarios. In the first case, $x$ is mobile and $y$ immobile. An input of $200 \%$ additional $x$ results in the desired rock composition, producing a volume increase of $50 \%$. In the second case, $x$ is immobile and $y$ is mobile. A leaching of $66 \%$ of the available $y$ produces a volume decrease of $50 \%$. Again, the same composition is obtained. This illustrates how important it is for mass balance calculations to (1) well define the nature of immobile elements or (2) take into account volume changes.

In this study, mass balances were calculated using the Isocon approach (Grant 1986) using the least-squares method assuming a Gaussian or log-normal concentration distribution (Baumgartner and Olsen 1995). This statistic treatment takes into account the standard deviation (SD) for each element of each studied rock population. It allows the selection of immobile chemical elements by identifying the maximum number of chemical elements that are, within their uncertainties, compatible with the same Isocon. Results obtained are shown in log-log concentration diagrams where chemical element concentrations for the unaltered rock (protolith) are plotted on the $x$-axis and those for the altered rock are plotted on the $y$-axis (Figs. 4, 
Table 1 Major and trace elements whole rock analyses of metacarbonate rocks from the Quérigut complex

\begin{tabular}{|c|c|c|c|c|c|c|c|c|c|c|c|c|c|c|c|}
\hline \multirow[t]{2}{*}{ Sample } & \multirow{2}{*}{\multicolumn{3}{|c|}{ Carbonate protolith $C_{\mathrm{p}}$}} & \multicolumn{2}{|c|}{ Septum core } & \multicolumn{5}{|c|}{ Laurenti $\gamma$} & \multicolumn{5}{|c|}{ Laurenti $\delta$} \\
\hline & & & & M40 & M41 & M37i & M37h & M37a & M37b & M37c & M39e & M39d & M39c & M39b & M39a \\
\hline Type & $n=9$ & $1 \sigma$ & & Marble & Marble & Marble & Marble & Marble & Marble & Skarn & Marble & Marble & Marble & Skarn & Skarn \\
\hline Distance $(\mathrm{cm})$ & & & & & & & & & 18 & & & & & & \\
\hline Cal (Wt \%) & 94 & 4 & & 96 & 91 & 91 & 97 & 47 & 53 & 51 & 81 & 89 & 83 & 29 & 10 \\
\hline Density & 2.70 & 0.10 & & 2.74 & 2.73 & & & 2.80 & 2.85 & 2.99 & 2.77 & 2.75 & 2.79 & 3.04 & 3.30 \\
\hline Wt $\%$ & $n=9$ & $1 \sigma$ & Mol \% & & & & & & & & & & & & \\
\hline $\mathrm{SiO}_{2}$ & 3.18 & 1.70 & 2.72 & 2.46 & 5.46 & 2.82 & 5.44 & 27.4 & 23.09 & 23.89 & 8.71 & 4.52 & 8.45 & 34.03 & 46.23 \\
\hline $\mathrm{TiO}_{2}$ & 0.07 & 0.04 & 0.04 & 0.05 & 0.08 & 0.08 & 0.12 & 0.47 & 0.40 & 0.35 & 0.18 & 0.08 & 0.17 & 0.34 & 0.28 \\
\hline $\mathrm{Al}_{2} \mathrm{O}_{3}$ & 1.04 & 0.52 & 0.53 & 0.92 & 1.48 & 1.16 & 1.91 & 9.26 & 8.08 & 7.17 & 3.79 & 1.57 & 3.60 & 7.31 & 14.20 \\
\hline $\mathrm{Fe}_{2} \mathrm{O}$ & 0.47 & 0.25 & 0.15 & 0.31 & 0.73 & 0.32 & 0.84 & 3.22 & 3.82 & 3.13 & 3.14 & 0.70 & 2.75 & 5.01 & 4.30 \\
\hline $\mathrm{MnO}$ & 0.05 & 0.03 & 0.03 & 0.03 & 0.02 & 0.04 & 0.15 & 0.10 & 0.11 & 0.13 & 0.16 & 0.05 & 0.17 & 0.26 & 0.21 \\
\hline $\mathrm{MgO}$ & 0.64 & 0.19 & 0.82 & 0.55 & 0.72 & 0.45 & 0.62 & 1.90 & 1.74 & 1.62 & 0.88 & 0.71 & 0.70 & 0.80 & 0.66 \\
\hline $\mathrm{CaO}$ & 52.08 & 1.23 & 47.69 & 52.78 & 50.48 & 52.02 & 49.74 & 33.23 & 36.49 & 39.11 & 46.03 & 51.18 & 46.55 & 38.73 & 27.85 \\
\hline $\mathrm{Na}_{2} \mathrm{O}$ & 0.00 & 0.00 & 0.00 & 0.00 & 0.00 & 0.01 & 0.06 & 0.16 & 0.13 & 0.00 & 0.08 & 0.00 & 0.08 & 0.00 & 0.24 \\
\hline $\mathrm{K}_{2} \mathrm{O}$ & 0.16 & 0.15 & 0.09 & 0.16 & 0.45 & 0.23 & 0.32 & 2.54 & 1.64 & 0.91 & 0.63 & 0.24 & 0.59 & 0.00 & 0.18 \\
\hline $\mathrm{P}_{2} \mathrm{O}_{5}$ & 0.05 & 0.02 & 0.02 & 0.03 & 0.04 & 0.02 & 0.04 & 0.09 & 0.09 & 0.10 & 0.05 & 0.06 & 0.04 & 0.15 & 0.13 \\
\hline LOI & 41.59 & 1.30 & & 41.88 & 39.93 & 41.92 & 39.63 & 20.82 & 23.46 & 22.86 & 35.75 & 40.09 & 35.97 & 13.14 & 5.14 \\
\hline $\mathrm{CO}_{2}$ & 41.07 & 1.16 & 47.92 & 42.11 & 39.93 & 39.87 & 42.49 & 20.89 & 23.32 & 22.48 & 35.65 & 39.04 & 36.67 & 12.77 & 4.58 \\
\hline Total & 99.33 & 0.14 & 100.00 & 99.18 & 99.38 & 99.06 & 98.86 & 99.20 & 99.04 & 99.28 & 99.39 & 99.21 & 99.09 & 99.75 & 99.42 \\
\hline ppm & $n=9$ & $1 \sigma$ & & & & & & & & & & & & & \\
\hline $\mathrm{Nb}$ & 2.0 & 1.2 & & 1.2 & 2.1 & 2.0 & 3.4 & 11.4 & 10.2 & 9.7 & 4.8 & 2.8 & 5.2 & 9.6 & 13.9 \\
\hline $\mathrm{Zr}$ & 29 & 14 & & 18 & 23 & 23 & 35 & 108 & 90 & 82 & 44 & 26 & 45 & 88 & 133 \\
\hline $\mathrm{Y}$ & 8.9 & 4.3 & & 4.1 & 4.8 & 4.8 & 10.5 & 19.3 & 21.7 & 21.2 & 13.0 & 11.3 & 13.3 & 25.3 & 26.5 \\
\hline $\mathrm{Sr}$ & 230 & 40 & & 201 & 236 & 182 & 252 & 330 & 299 & 307 & 220 & 271 & 231 & 166 & 233 \\
\hline $\mathrm{U}$ & $<2$ & $<2$ & & $<2$ & $<2$ & $<2$ & $<2$ & $<2$ & $<2$ & $<2$ & $<2$ & $<2$ & $<2$ & 24 & 19 \\
\hline $\mathrm{Rb}$ & 7.1 & 4.3 & & 6.4 & 13.6 & 8.8 & 9.4 & 88.6 & 59.6 & 31.2 & 22.2 & 8.8 & 30.5 & $<1$ & 5.5 \\
\hline Th & 3 & 1 & & 3 & 4 & 2 & 4 & 8 & 8 & 9 & 4 & 4 & 3 & 9 & 17 \\
\hline $\mathrm{Pb}$ & 3 & 2 & & 2 & 4 & $<2$ & 7 & 9 & 6 & 4 & 13 & 20 & 14 & 4 & 5 \\
\hline $\mathrm{Ga}$ & 5 & 1 & & 5 & 5 & 5 & 5 & 14 & 13 & 12 & 8 & 6 & 7 & 13 & 18 \\
\hline $\mathrm{Zn}$ & 17 & 11 & & 12 & 15 & 10 & 25 & 40 & 41 & 49 & 30 & 37 & 33 & 55 & 45 \\
\hline $\mathrm{Ni}$ & 2 & 3 & & $<2$ & $<2$ & $<2$ & 12 & 16 & 14 & 11 & 9 & 9 & 7 & 141 & 84 \\
\hline $\mathrm{Cr}$ & 8 & 3 & & 7 & 7 & 6 & 7 & 48 & 40 & 38 & 17 & 10 & 17 & 41 & 29 \\
\hline V & 9 & 4 & & 5 & 6 & 3 & 6 & 56 & 47 & 40 & 30 & 14 & 26 & 287 & 181 \\
\hline $\mathrm{Ce}$ & 4 & 4 & & $<3$ & $<3$ & $<3$ & $<3$ & 35 & 32 & 30 & 7 & $<3$ & 16 & 24 & 38 \\
\hline $\mathrm{Ba}$ & 36 & 23 & & 41 & 59 & 38 & 93 & 271 & 207 & 192 & 88 & 64 & 133 & 19 & 98 \\
\hline $\mathrm{La}$ & 7 & 5 & & $<4$ & 2 & 12 & 19 & 25 & 24 & 23 & 9 & 4 & 10 & 30 & 40 \\
\hline
\end{tabular}

Data for the two profiles were sampled in a single metacarbonate xenolith. Samples M40 and M41 were used for mass balance calculations for both profiles since they are in the middle of the xenolith. Distances are reported with reference to the granitoid-carbonate contact. M40 is located at $550 \mathrm{~cm}$ from the contact of the granodiorite and M41 is located at $600 \mathrm{~cm}$ from the contact of the granite. The average of nine unaffected carbonate samples, used as the protolith composition, is reported with their SD $(1 \sigma)$. Also reported are weight percent total carbonate data and density data

5). Major and trace element concentrations are expressed in $\mathrm{g} / 100 \mathrm{~g}$ and $10^{-6} \mathrm{~g} / 100 \mathrm{~g}$, respectively. In such diagrams, the Isocon is defined by:

$\log C_{\mathrm{i}}^{\mathrm{A}}=\log \left(\frac{M^{0}}{M^{\mathrm{A}}}\right)+\log C_{\mathrm{i}}^{0}$

where $C_{\mathrm{i}}^{0}$ and $C_{\mathrm{i}}^{\mathrm{A}}$ are the concentrations of an element $\mathrm{i}$ in the protolith (0) and in the altered sample (A), respectively.
$M^{0}$ and $M^{\mathrm{A}}$ are the total masses of the protolith and the altered sample, for the reference system. Note that the straight line always has a slope of one in this diagram. Chemical elements below the Isocon left the system whereas chemical elements above the Isocon were introduced into the system. If the intercept is negative, a mass increase occurred during alteration $\left(M^{\mathrm{A}}>M^{0}\right)$. If it is positive, a mass decrease occurred $\left(M^{\mathrm{A}}<M^{0}\right)$. Note that 
Fig. 3 Diagrams of $\mathrm{SiO}_{2}$ and $\mathrm{CO}_{2}$ versus $\mathrm{CaO}$ show the chemical evolution of the carbonate as the igneous contact is approached. Data from the two profiles are given, along with various samples collected in the aureole. Note the chemical variability of the carbonates used to define the protholith composition
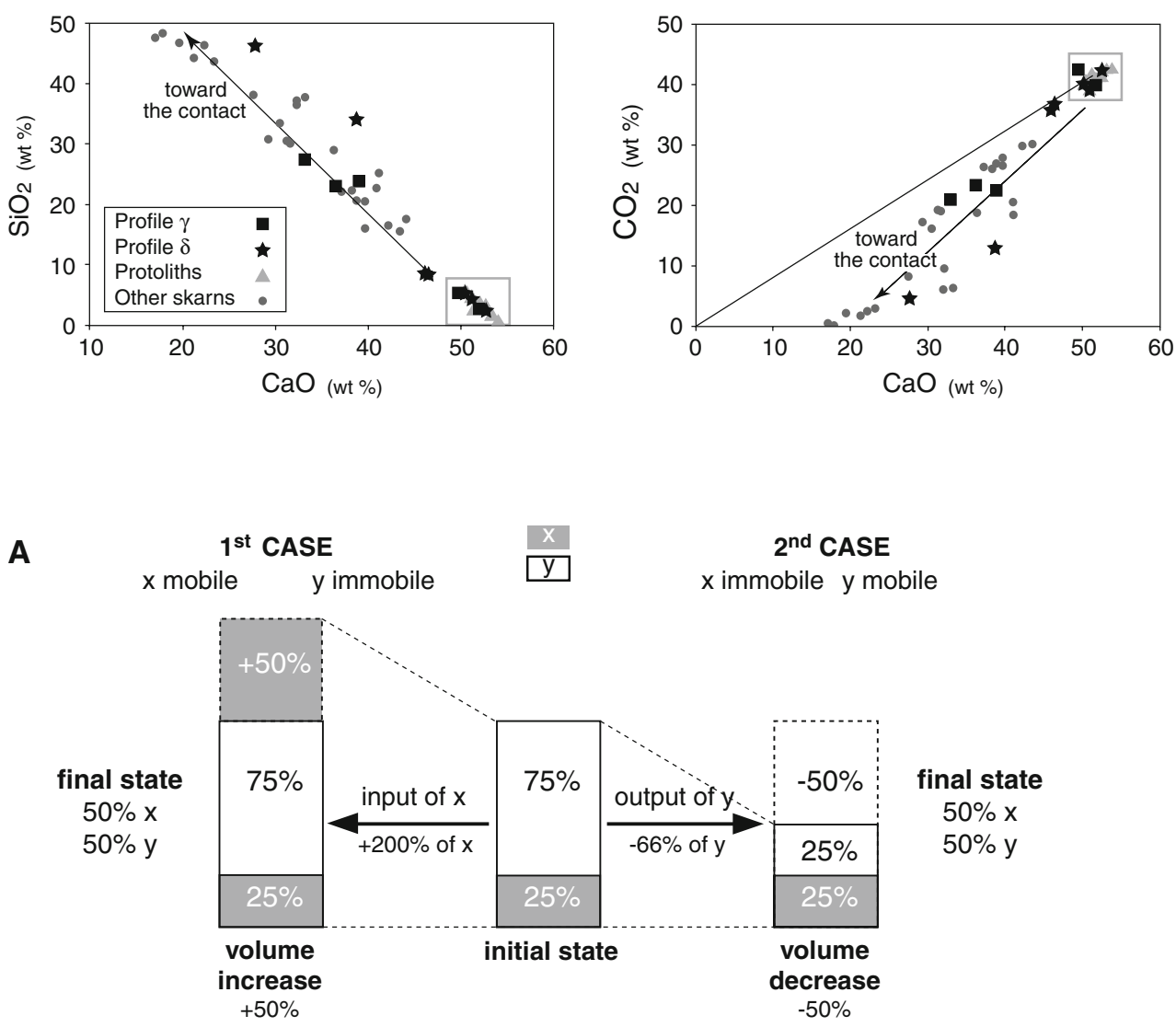

Fig. 4 a Two alternative mass transfer scenarios can produce the same final rock composition, starting with the same initial composition. This illustrates the importance to (1) accurately define the protolith composition, and (2) to account correctly for the volume changes during mass transfer, by identifying for example immobile elements. b Resulting log-log Isocon diagrams calculated for the above two mass transfer scenarios. Both could potentially explain the geochemical data observed in the metacarbonate septa. Model 1: addition of $30 \mathrm{~mol}$ of $\mathrm{SiO}_{2}$ and $15 \mathrm{~mol}$ of $\mathrm{MgO}$ resulting in a slight volume gain $(+12 \%)$. Model 2: a loss of $80 \mathrm{~mol}$ of $\mathrm{CaO}$ and $\mathrm{CO}_{3}$ from the metacarbonate protolith. This model produces a large volume loss $(-85 \%)$

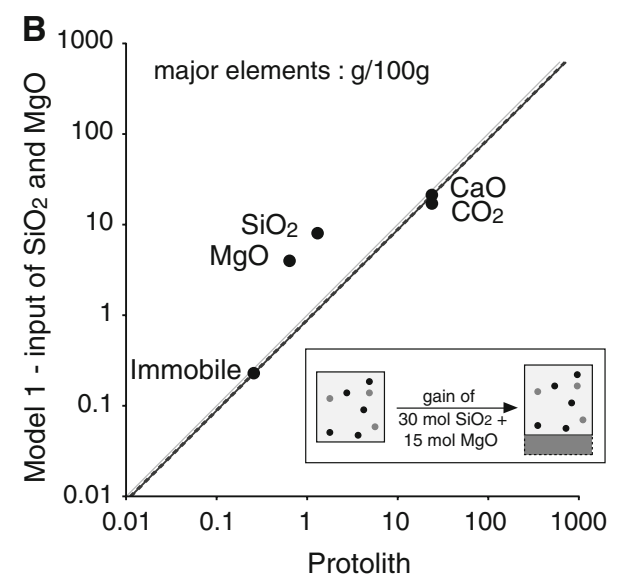

concentration changes can occur due to (1) density and/or volume changes resulting from the formation of a new mineral assemblage and/or (2) the flux of chemical elements between the system and its surroundings.

\section{Mass balance modelling}

Inspection of the analysis (Table 1) reveals that the metasomatism is characterized by a decrease in $\mathrm{CaO}$ and $\mathrm{CO}_{2}$ contents correlated with an increase in elements contained in calc-silicate minerals (e.g. $\mathrm{SiO}_{2}, \mathrm{Al}_{2} \mathrm{O}_{3}, \mathrm{FeO}$,
$\mathrm{MgO}$, etc.). Such a mineralogical and geochemical evolution is typical for the formation of skarns. It is commonly interpreted as the result of extensive addition of elements from the intrusion (Einaudi and Burt 1982; Brown and Essene 1985; Nabelek and Labotka 1993; Gerdes and Valley 1994; Buick and Cartwright 2002; Ferry et al. 2002), typically due to the infiltration of aqueous fluids of magmatic origin which carry with them abundant silicate, aluminium and bivalent cations (Nabelek and Labotka 1993; Gerdes and Valley 1994; Buick and Cartwright 2002; Abu El-Enen et al. 2004). An 
Fig. 5 Log-log diagrams for the profile $\delta$ showing the chemical evolution of metacarbonates towards the igneous contact. A large loss of $\mathrm{CaO}, \mathrm{Sr}, \mathrm{MgO}$ and $\mathrm{CO}_{2}$ in the marble and exoskarns is partially compensated by a slight increase in $\mathrm{SiO}_{2}, \mathrm{Al}_{2} \mathrm{O}_{3}$ and $\mathrm{Fe}_{2} \mathrm{O}_{3}$ in the exoskarns immediately adjacent to the igneous contact. Chemical compositions used for massbalance calculations are given in Table 2. Error bars are $1 \sigma \mathrm{SD}$, based on protolith heterogeneity. See text for explanations
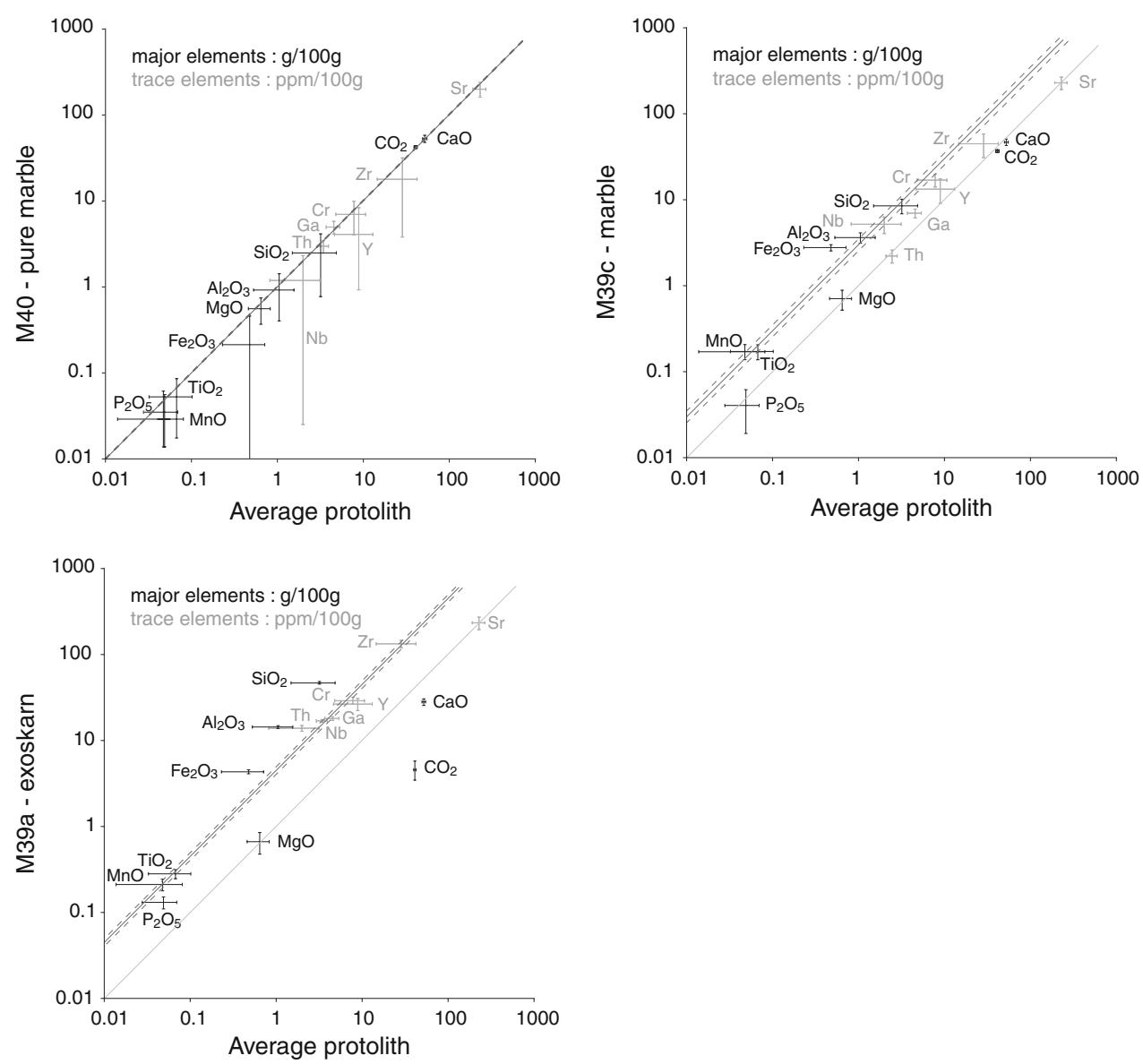
Table 2 The two different scenarios of mass transfer illustrated in Fig. 4 result in about the same whole rock compositions

\begin{tabular}{|c|c|c|c|c|c|c|c|}
\hline & & $\mathrm{SiO}_{2}$ & $\mathrm{MgO}$ & $\mathrm{CaO}$ & $\mathrm{CO}_{2}$ & Immobile & Total \\
\hline \multirow[t]{2}{*}{ Initial model composition } & Mol & 5.00 & 2.50 & 92.50 & 92.50 & 1.00 & 193.50 \\
\hline & Mol \% & 2.59 & 1.29 & 47.80 & 47.80 & 0.52 & 100.00 \\
\hline \multirow[t]{2}{*}{ Model 1 (open system) input of $+30 \mathrm{~mol} \mathrm{SiO}_{2}+15 \mathrm{~mol} \mathrm{MgO}$} & Mol & 35.00 & 17.50 & 92.50 & 75.00 & 1.00 & 221.00 \\
\hline & Mol \% & 15.84 & 7.92 & 41.86 & 33.94 & 0.45 & 100.00 \\
\hline \multirow[t]{2}{*}{ Model 2 (closed system) output of $-80 \mathrm{~mol}\left(\mathrm{CaO}+\mathrm{CO}_{2}\right)$} & Mol & 5.00 & 2.50 & 12.50 & 10.00 & 1.00 & 31.00 \\
\hline & Mol \% & 16.13 & 8.06 & 40.32 & 32.26 & 3.23 & 100.00 \\
\hline
\end{tabular}

The addition of $\mathrm{SiO}_{2}$ and $\mathrm{MgO}$ (Model 1) or the loss of $\mathrm{CaO}$ and $\mathrm{CO}_{2}$ (Model 2) can potentially account for the observed rock compositions. Note that the initial and final compositions used in the model are close to the chemical compositions of the carbonate protolith and an altered sample, respectively

\section{Model 2: mass loss}

This model involves loss of stoichiometric "calcite", hence $\mathrm{CO}_{2}$ and $\mathrm{CaO}$ are removed from the system. This process produces a passive concentration increase of all immobile elements. A total of $80 \mathrm{~mol}$ of calcite $\left(\mathrm{CaO}\right.$ and $\left.\mathrm{CO}_{2}\right)$ are lost from the metacarbonate protolith (Table 2). The calcite breakdown is associated with formation of diopside and release of $\mathrm{CO}_{2}$ during decarbonation reactions. This process can be summarized by the following reaction:

$$
\begin{aligned}
& {\left[92.5 \mathrm{~mol}\left(\mathrm{CaO}+\mathrm{CO}_{2}\right)+5 \mathrm{~mol} \mathrm{\textrm {SiO } _ { 2 }}+2.5 \mathrm{~mol} \mathrm{MgO}\right.} \\
& \quad+1 \mathrm{~mol} \mathrm{immobile}]_{(\text {initial })} \rightarrow 2.5 \mathrm{~mol} \mathrm{CaMgSi} \mathrm{O}_{6} \text { (formed) } \\
& \quad+10 \mathrm{~mol} \mathrm{CaCO} \text { (residual) }+1 \mathrm{~mol} \mathrm{immobile}{ }_{(\text {residual })} \\
& \quad+2.5 \mathrm{~mol} \mathrm{CO} \text { (output by decarbonation reaction }) \\
& \quad+80 \mathrm{~mol}\left(\mathrm{CaO}+\mathrm{CO}_{2}\right)_{(\text {output })}
\end{aligned}
$$

The Isocon is defined by the immobile elements including $\mathrm{SiO}_{2}$ and $\mathrm{MgO}$ (Fig. 4b). Both $\mathrm{CaO}$ and $\mathrm{CO}_{2}$ plot below the Isocon because they were lost from the system. It is noteworthy that $\mathrm{CaO}$ plots slightly above $\mathrm{CO}_{2}$ because additional $\mathrm{CO}_{2}$, produced by the decarbonation reaction (3), escapes the system (Fig. 4b). In this model the estimated volume loss is about $85 \%$ (assuming a constant density).

\section{Mass balance results}

Here, mass balance results obtained from profiles $\delta$ and $\gamma$ are presented (Table 3 ). These results will be compared to both previous models to identify the mass transfer process in the metacarbonate xenolith. Three logarithmic Isocon diagrams for profile $\delta$ are presented in Fig. 5. They illustrate the mass transfer as the contact is approached. The shown uncertainty corresponds to the protolith SD $(1 \sigma)$ which is considered to represent the uncertainties of analysis and the heterogeneity of the protolith.

M40 was sampled at $550 \mathrm{~cm}$ from the contact. All elements plot on the same straight line. Hence, all elements are considered as immobile which suggest no chemical mass transfer. The mass change ratio, of $1.0116 \pm 0.0224$, implies no mass change (no density and volume change). Hence, sample M40 has not been affected by the granodiorite emplacement. This also shows that the nine samples used to calculate the protolith are indeed similar to the xenolith carbonates.

The diagrams calculated for the two others samples (M39c and M39a) sampled at 100 and $5 \mathrm{~cm}$ from the contact, respectively, show a significant and increasing change in composition. $\mathrm{CaO}, \mathrm{CO}_{2}, \mathrm{Sr}$ and $\mathrm{MgO}$ are identified as mobile. They further decrease towards the contact while most other chemical elements (like $\mathrm{SiO}_{2}, \mathrm{TiO}_{2}, \mathrm{Al}_{2} \mathrm{O}_{3}$, $\mathrm{MnO}, \mathrm{Zr}, \mathrm{Nb}$ ) plot on the straight line, and are hence interpreted to be immobile. Note that in the sample closest to the contact (M39a), an addition of $\mathrm{SiO}_{2}, \mathrm{Al}_{2} \mathrm{O}_{3}$ and $\mathrm{Fe}_{2} \mathrm{O}_{3}$, probably from the intrusive rock, is suggested, along with a large loss of $\mathrm{CaO}, \mathrm{CO}_{2}, \mathrm{Sr}$ and $\mathrm{MgO}$ (Fig. 6; Table 3). Figure 6 illustrates well the significant loss in $\mathrm{CaO}$ and $\mathrm{CO}_{2}$ contents toward the contact zone. $M^{0} / M^{\mathrm{A}}$ ratios evolve from $1.0116 \pm 0.0224$ (sample M40) toward a maximum value of $4.4732 \pm 0.4525$ at the contact (sample M39a). The observed evolution implies a large mass decrease of up to $-78 \pm 2 \%$ (sample M39a) and hence also a large volume decrease (up to $-81 \pm 7 \%$ ). Note that a density increase appears toward the contact (up to $17 \pm 3 \%$ in sample M39a; Table 3) due to mineral assemblage changes. This accentuates the volume loss. Similar results are obtained for profile $\gamma$. A large loss of $\mathrm{CaO}, \mathrm{Sr}$ and $\mathrm{CO}_{2}$, without any addition of $\mathrm{SiO}_{2}, \mathrm{Al}_{2} \mathrm{O}_{3}$ and $\mathrm{Fe}_{2} \mathrm{O}_{3}$ in the vicinity of the contact, explains the data completely. Mass shows again a significant decrease $(-85 \pm 2 \%)$, accompanied by a volume decrease $(-86 \pm 6 \%)$. Density again increases $(11 \pm 3 \%)$ toward the contact (sample M37c; Table 3).

\section{Discussion}

Mass transfer in metacarbonates: decarbonation and calcite loss processes

The mineralogical and geochemical evolution in the metacarbonate xenolith documents mass transfer during 


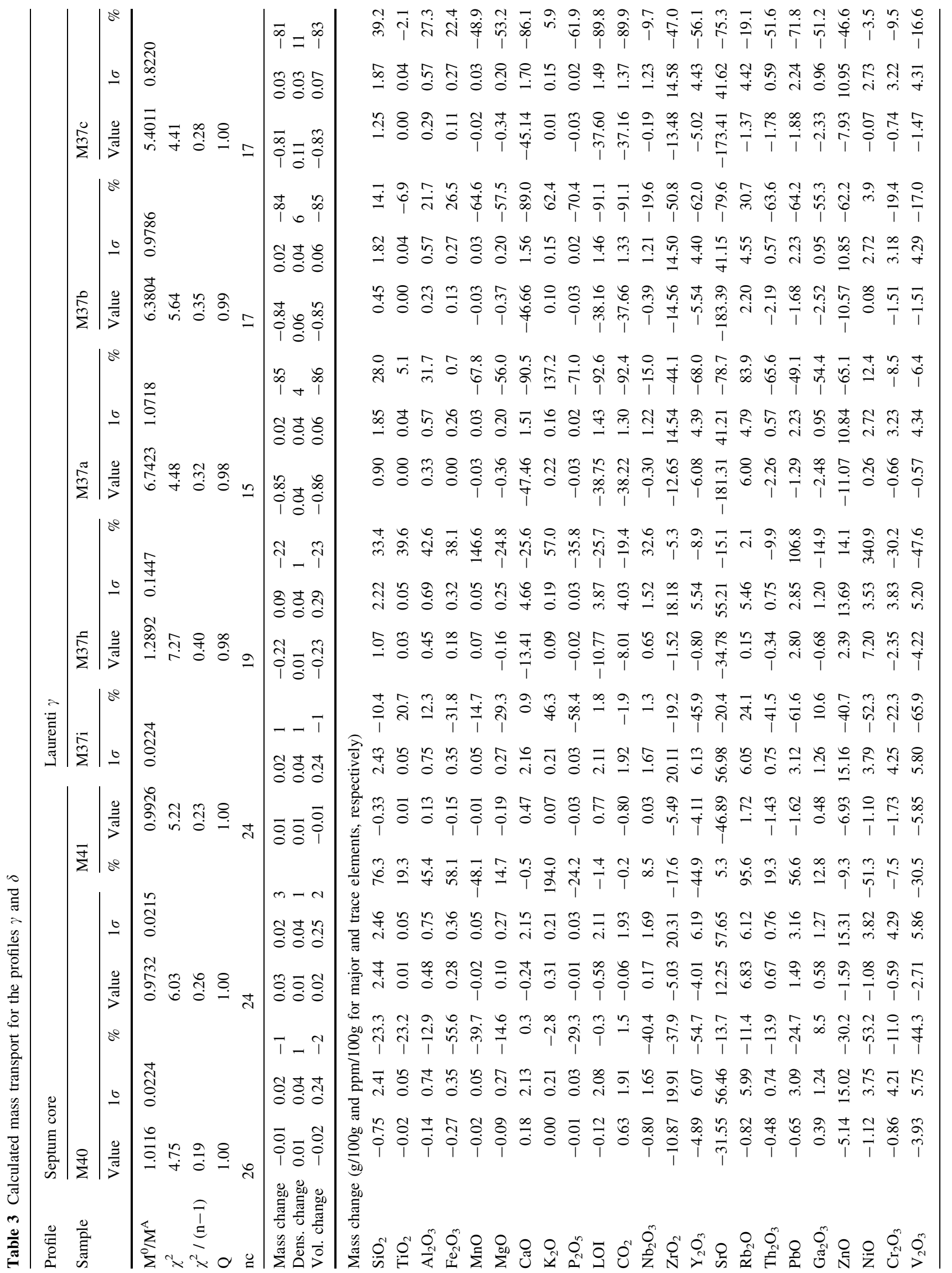




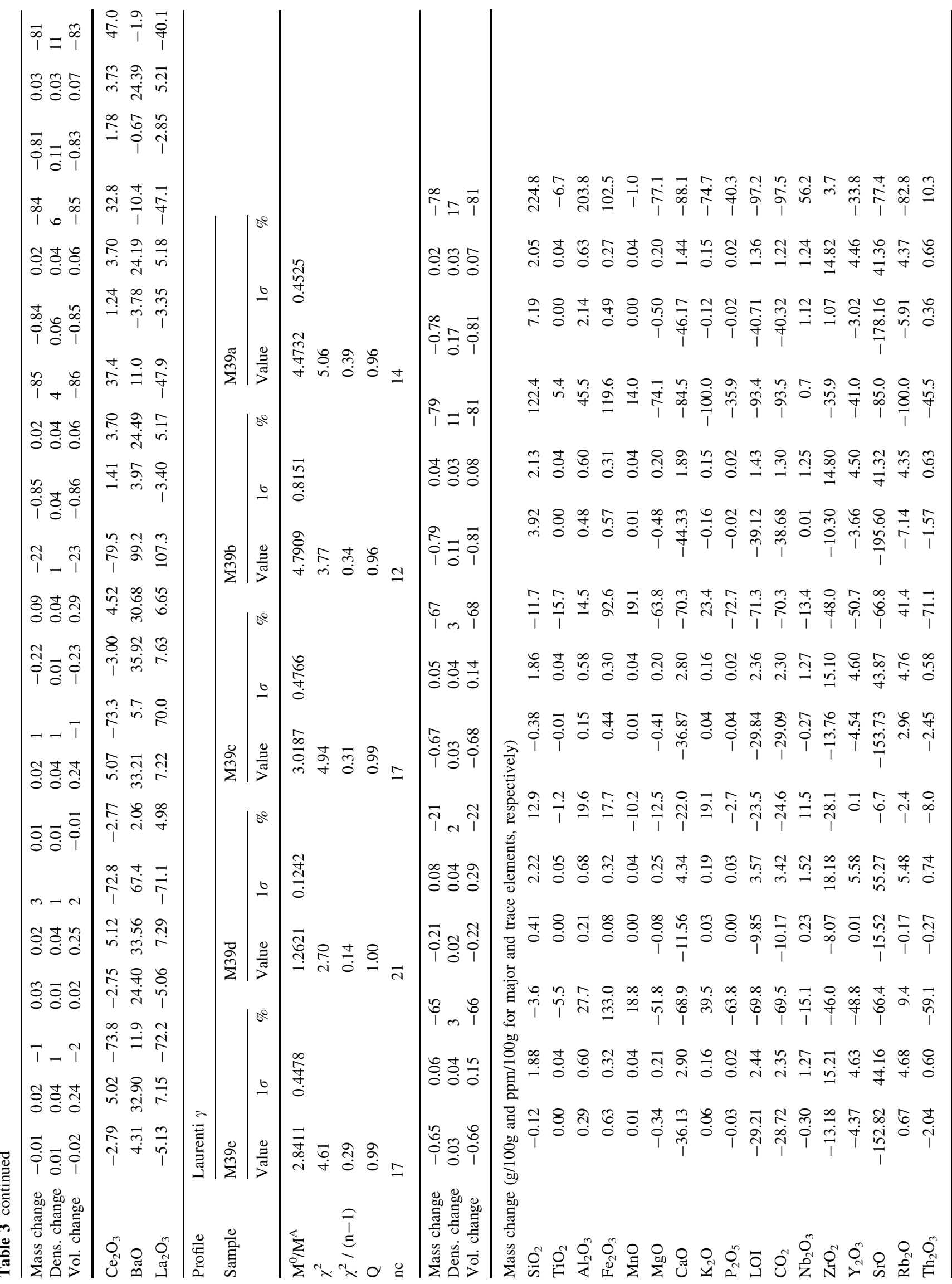




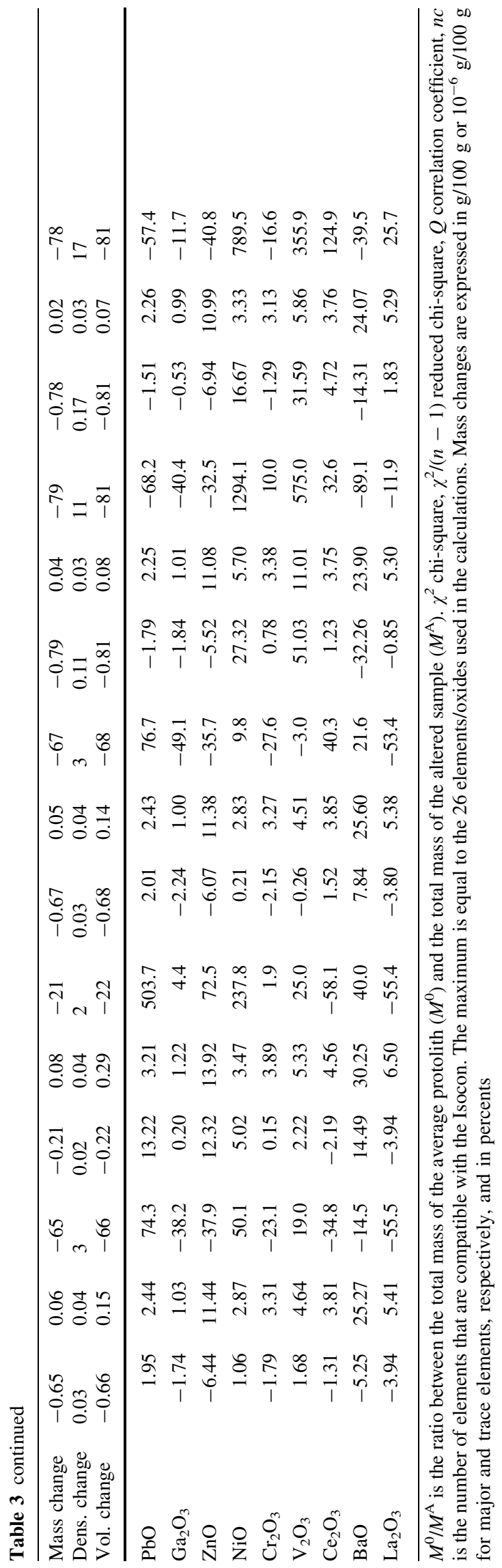

contact metamorphism. It appears that the "mass loss" model reproduces completely the observed data: (1) chemical elements, found in carbonates $(\mathrm{CaO}, \mathrm{MgO}, \mathrm{Sr}$ and $\mathrm{CO}_{2}$ ), are mobile and partially lost from the system and (2) a significant volume loss of up to $86 \%$ occurred (Figs. 6, 7; Tables 2, 3). The $\mathrm{Sr}$ decrease is linked to the $\mathrm{CaO}$ decrease due to their similar geochemical behaviour (Rollinson 1993). Most of the other chemical elements are passively concentrated during calcite loss (Fig. 6). No large element input from an external reservoir (e.g. adjacent granitic rocks) is required. Only a small amount of $\mathrm{SiO}_{2}, \mathrm{Al}_{2} \mathrm{O}_{3}$ and $\mathrm{Fe}_{2} \mathrm{O}_{3}$ is needed in the immediate vicinity of the contact in profile $\delta$ (Fig. 7; Table 3). Despite the fact, that, e.g. the $\mathrm{SiO}_{2}$ content increases for about $225 \pm 64 \%$ (sample M39a; Table 3), this increase corresponds to an addition of $7.19 \pm 2.05 \mathrm{~g} \mathrm{SiO}_{2}$ per $100 \mathrm{~g}$ of rock, probably from the igneous rock. This represents a minor process in comparison to the loss of $86.5 \pm 2.7 \mathrm{~g}$ $\mathrm{CaCO}_{3}$ per $100 \mathrm{~g}$ of total rock from the metacarbonate xenolith (Fig. 6; Table 3).

The passive concentration of immobile elements during skarn formation can thus be modelled as a function of the amount of carbonate ( $100 \%$ calcite) removed from the carbonate protolith. Results for $\mathrm{Al}_{2} \mathrm{O}_{3}, \mathrm{TiO}_{2}$ and $\mathrm{Nb}$ are presented in Fig. 8. A good correlation is observed between predicted and observed evolution, which supports the model of skarn formation by loss of calcite without a large input of external elements. This diagram also shows that sample located in the vicinity of intrusive rocks have lost about $90 \%$ of calcite.

In addition to calcite loss, new calc-silicate minerals appear toward the contact zone by decarbonation reactions (Cpx, Grt, Wo and Czo). The $\mathrm{CaO}-\mathrm{CO}_{2}$ diagram (Fig. 3b) shows that the loss of $\mathrm{CaO}$ was less important than the loss of $\mathrm{CO}_{2}$. This is consistent with a process of decarbonation where additional $\mathrm{CO}_{2}$ leaves the system.

Note that the presence of such calcite loss process could occur in other contact metamorphism environments and could be overlooked by other effective processes in such environments.

Volume loss

Mass balance calculations show that up to $86 \pm 6 \%$ of the initial volume is lost during contact metamorphism (Table 3, Fig. 9). However, this maximum value of mass loss is restricted to the immediate vicinity of the contact.

Some authors make the assumption that volume remains constant in marbles during contact metamorphism (Ferry 1994; Abu El-Enen et al. 2004). From our results, the assumption of constant volume during contact metamorphism might be incorrect. Volume changes must be taken into account. In this case, volume variation results from (1) 
Fig. 6 Mass balance results for profile $\delta$. Mass transports for major elements are presented as mass changes $(\mathrm{g} / 100 \mathrm{~g})$ of the carbonate protolith. The name of an element is indicated only if a gain or a loss in the content of this element occurs. Error bars are $1 \sigma \mathrm{SD}$
Fig. 7 The change in mass for the main mobile major elements $(\mathrm{g} / 100 \mathrm{~g})$ is plotted as a function of distance to the contact with intrusive rocks for profiles $\gamma$ and $\delta$. A large loss of $\mathrm{CaO}$ and $\mathrm{CO}_{2}$ is observed toward the contact zone in both profiles. A small gain of $\mathrm{SiO}_{2}$ and $\mathrm{Al}_{2} \mathrm{O}_{3}$ is recorded only in the $\delta$ profile. Error bars are $1 \sigma \mathrm{SD}$
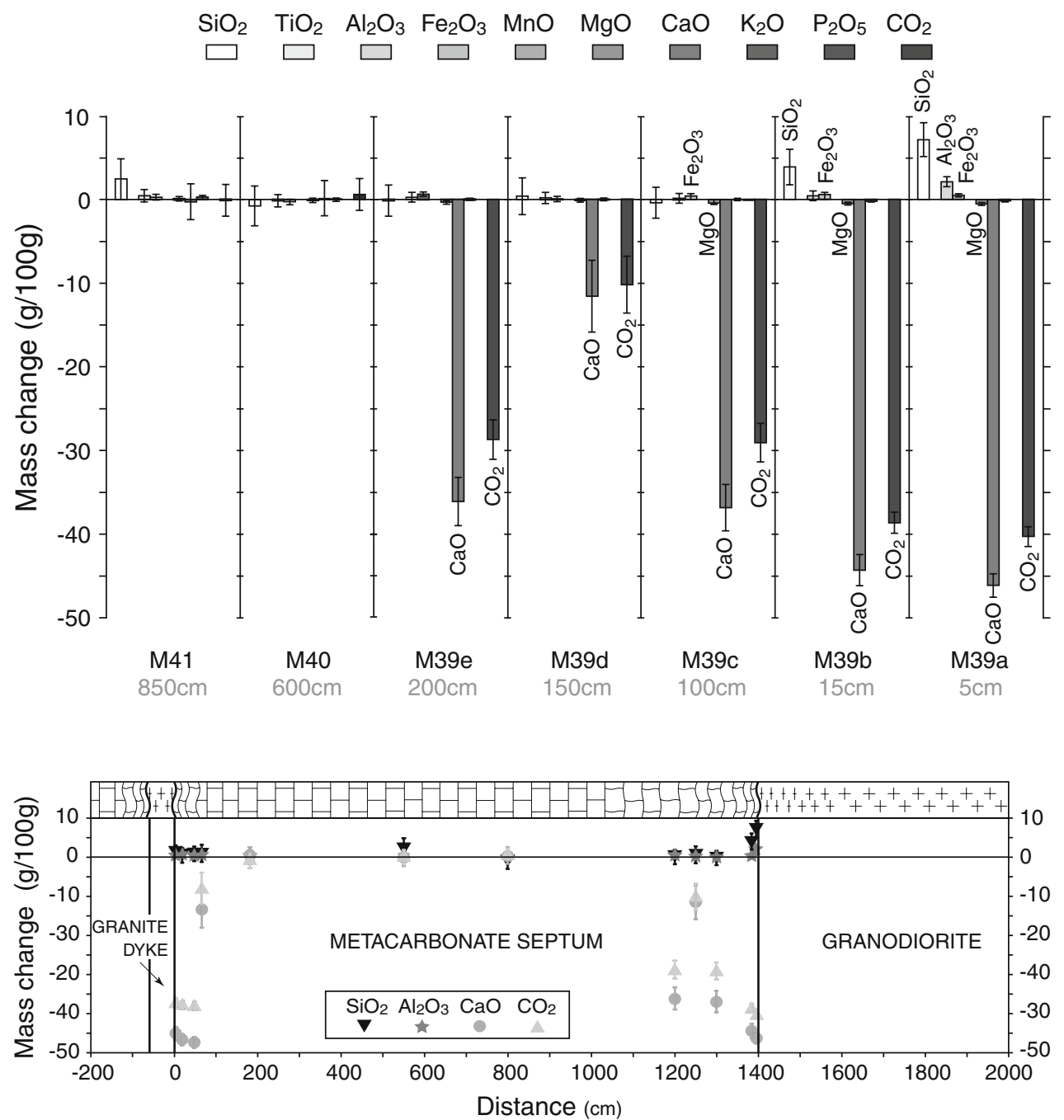

the breakdown of calcite, (2) a loss of $\mathrm{Ca}$ and volatiles. Locally, an addition of Al, Si and often Fe partially compensates for this loss. Tracy et al. (1983) also suggest a strong volume loss in impure marble adjacent to a quartz vein-filled fracture ( $>50 \%$ of the initial rock volume) during regional metamorphism.

\section{Effects of volume loss on stable isotope profiles}

Volume changes which occur in metacarbonate xenoliths during contact metamorphism can influence the shape of stable isotope profiles (Fig. 10). Tracy et al. (1983) have already discussed the effects of volume loss on Rayleigh fractionation and box-model calculations.

To illustrate the effect of volume change on $\mathrm{O}$ stable isotope profiles, the initial position of each studied samples is recalculated by integrating volume losses along each profile, using an increment of $10 \mathrm{~cm}$ (based on linearly interpolating between samples). Recalculated initial positions of studied samples are given in Table 4. The actual lengths of profiles $\gamma$ and $\delta$ are 800 and $850 \mathrm{~cm}$, respectively. After corrections for volume loss, these two profiles have lengths of around 1,100 \pm 200 and 1,300 $\pm 380 \mathrm{~cm}$, respectively. Hence, each profile was significantly longer before the metasomatic volume loss, by about 300 and $450 \mathrm{~cm}$, respectively.

Oxygen and carbon stable isotope profiles measured across the metacarbonate-intrusive rock contacts have already been described in details in Durand et al. (2006). In order to compare isotopic values of granodioritic and metecarbonate rocks, the oxygen isotope composition of calcite in equilibrium with quartz was calculated (at $500^{\circ} \mathrm{C}$ ) where no carbonate is present. The "ISOfit" program (personal communication Baumgartner, unpublished) was used to fit isotope profiles with a 1D transport equation. It fits analytic solution of the advection-diffusion equation (Baumgartner and Rumble III 1988) to measured data using a least-square fitting procedure (Marquardt 1963). Local equilibrium (Thompson 1959) between carbonate and fluids is assumed. Output of the model is, among other 


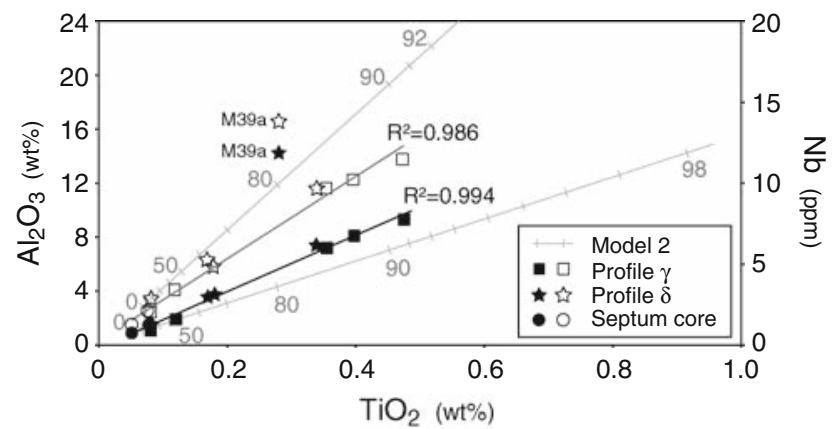

Fig. 8 Geochemical modelling of the evolution of major and trace element contents using a calcite loss model. The starting composition used in this model is the carbonate protolith (Table 2). The tick marks along the lines refer to the amount of pure calcium carbonate lost. The measured data is plotted for both profiles, using $\mathrm{TiO}_{2}$ as the inert component. Excellent $R^{2}$ were obtained which indicates that $\mathrm{TiO}_{2}$, $\mathrm{Al}_{2} \mathrm{O}_{3}$ and $\mathrm{Nb}$ evolve in the same proportion and, hence, are immobile. Excellent agreement between modelled and observed values exists. This indicates that the increase in $\mathrm{TiO}_{2}, \mathrm{Al}_{2} \mathrm{O}_{3}$ and $\mathrm{Nb}$ contents can be explained by a loss of calcite. Only sample M39a sampled at $5 \mathrm{~cm}$ from the granodiorite intrusion does not fully fit. Note that the three chosen immobile elements $\left(\mathrm{TiO}_{2}, \mathrm{Al}_{2} \mathrm{O}_{3}\right.$ and $\left.\mathrm{Nb}\right)$ are not present in the same mineral phase. Their chemical evolution does hence not depend on the modal abundance of a single mineral. $\mathrm{Al}_{2} \mathrm{O}_{3}$ and $\mathrm{Nb}$ are plotted with black and open symbols, respectively

values, the Peclet number, calculated for each profile. The Peclet number, a dimensionless transport variable, allows estimating the ratio of infiltration to diffusion during metasomatism (Bear 1988; Bowman and Willett 1991; Baumgartner and Valley 2001).

Four different $\mathrm{O}$ stable isotope profiles, labelled from 1 to 4, are presented in Fig. 10. Curve 1 represents the actual state and reports $\delta^{18} \mathrm{O}$ as a function of the measured distances (Fig. 10a). $\delta^{18} \mathrm{O}$ values decrease toward the contact from the sedimentary values of $24 \%$ which is preserved in the xenolith core (M40 and M41), towards 14.8\%o near the contact. $\delta^{18} \mathrm{O}$ values of calcite in equilibrium with granodiorite increase from magmatic values of $11-12.5 \%$, for samples located far from the contact, to higher values for altered samples located near the carbonate contact $\left(\delta^{18} \mathrm{O}=14.5-15.2 \%\right)$. The observed $\delta^{18} \mathrm{O}$ evolution is consistent with dominantly diffusive isotopic exchanges between two contrasting rocks (Taylor and O'Neil 1977;
Valley 1986; Cartwright and Valley 1991; Nabelek 1991; Turner and Bowman 1993; Cartwright et al. 1997; Buick and Cartwright 2000; Baumgartner and Valley 2001; Buick and Cartwright 2002). Least square fit to the data reveal some infiltration. Small Peclet numbers $(5.8 \pm 1.5$ and $7.6 \pm 1.7)$ result from fits to the $\gamma$ and $\delta$ profiles, as expected. This suggests that the profile were mainly controlled by diffusion across the contact, with only limited fluid flow perpendicular to the granitic rock contact.

The initial $\delta^{18} \mathrm{O}$ composition, before contact metamorphism, is given by curve 3 (Fig. 10b). This initial state is characterized by sedimentary values in metacarbonate rocks (around 24\%o) and igneous values in intrusive rocks (between 12 and 13.5\%).

During contact metamorphism, two different processes affect the initial profile: $\mathrm{O}$ alterations by diffusion/advection in granitic and metacarbonate rocks and volume losses associated with chemical mass transfers in metacarbonates. The relative chronology between $\mathrm{O}$ alteration and metasomatism is unknown, but three different cases can be invoked: (1) the $\mathrm{O}$ isotope alteration is posterior to the volume loss process, (2) the $\mathrm{O}$ isotope alteration is prior to the volume loss process and (3) the $\mathrm{O}$ isotope alteration and the volume loss processes are contemporaneous. Note that the alteration profiles in cases (2) and (3) will be strongly influenced by the volume change.

Here, we present the first two end-member cases (Fig. 10). If $\mathrm{O}$ alteration is posterior to volume loss (1), the isotope composition does not change during volume loss and the profile evolves from the curve 3 to the curve 2 . Isotope alteration occurs afterwards. The isotope profile evolves from the curve 2 to the curve 1 . If isotope alteration is prior to volume loss (2), the initial isotope profile length was greater than the measured length, after volume loss. In this case, the $\mathrm{O}$ alteration evolves from the curve 3 , representing the initial state, to the curve 4 . This is following by volume loss during metasomatism and the alteration profile evolves from curve 4 to the today measured profile (curve 1). Initial $\mathrm{O}$ alteration distances (L) were about 250 and $1,500 \mathrm{~cm}$, respectively. These have to been compared with today's values of 100 and $600 \mathrm{~cm}$ for profiles $\gamma$ and $\delta$, respectively. Thus, if isotope alteration is
Fig. 9 Evolution of volume change as a function of distance to the contact with intrusive rocks, for profiles $\gamma$ and $\delta$. The volume change corresponds to the ratio of $V^{\mathrm{A}} / V^{0}$ where $V^{\mathrm{A}}$ is the volume of the altered sample and $V^{0}$ is the volume of the protolith. A large volume loss, with $V^{\mathrm{A}} / V^{0}$ of about $0.10-0.20$, results from $\mathrm{CaO}$ and $\mathrm{CO}_{2}$ losses

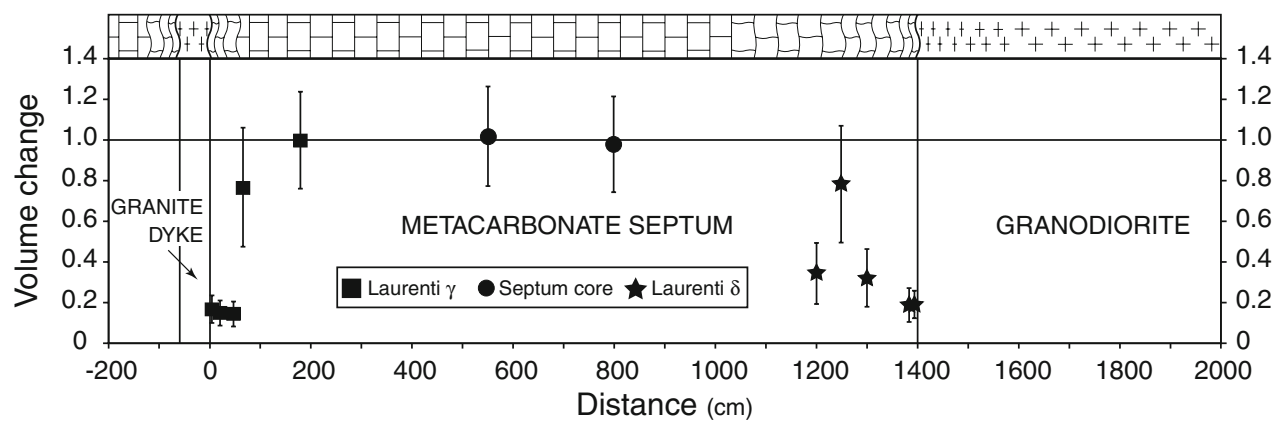



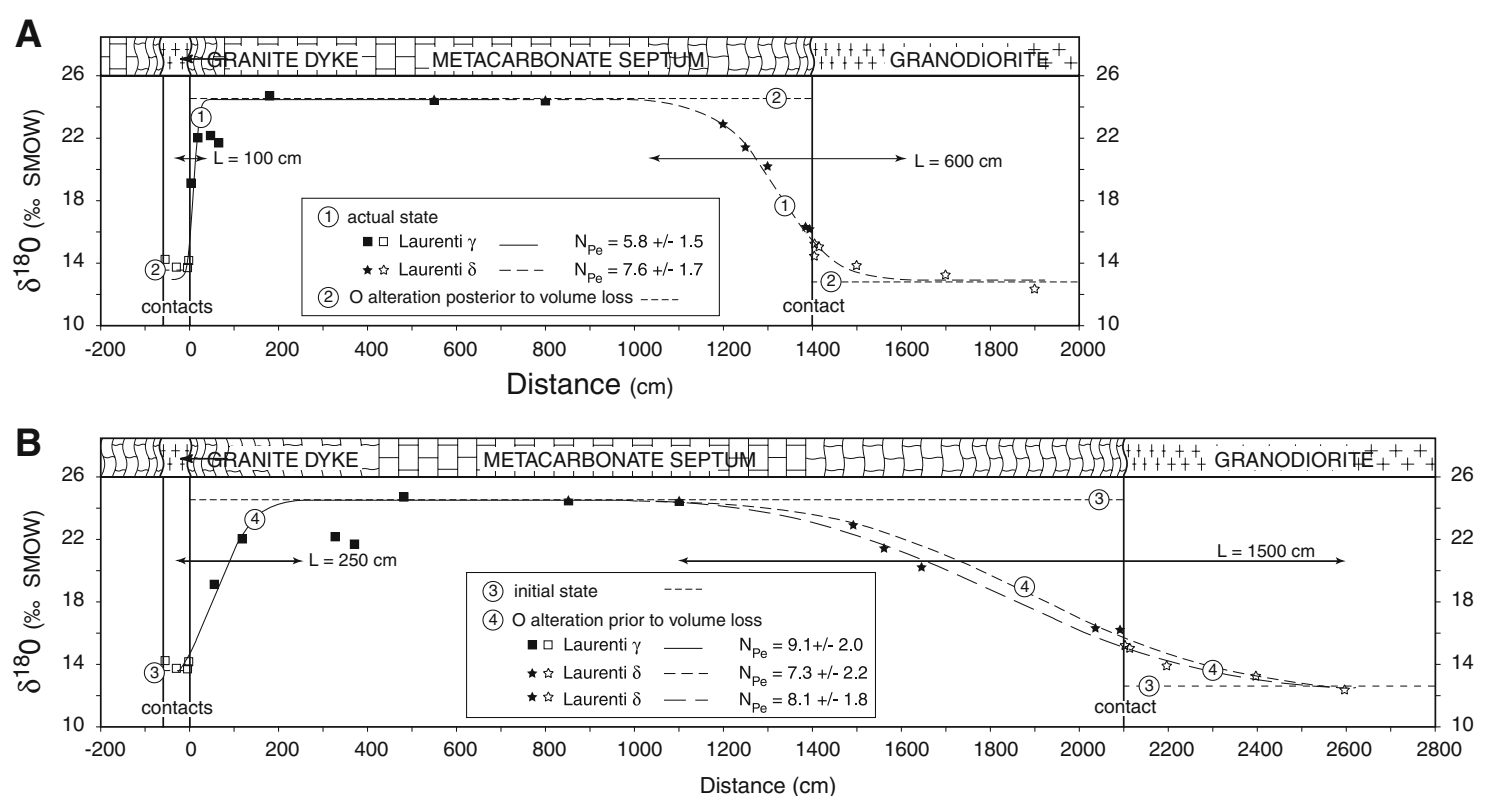

Fig. 10 Some possible effects of volume loss on the interpretation of stable isotopic profiles. a Oxygen stable isotope profiles are plotted using actually measured distances for samples. Curve 1 gives the measured values after the $\mathrm{O}$ alteration and the volume loss. Curve 2 illustrates the initial conditions if volume loss occurred prior to the isotope alteration. b Oxygen stable isotope composition profiles are plotted against distance taking into account the volume loss that

Table 4 Integrated profile length, taking into account volume changes

\begin{tabular}{lrrr}
\hline Sample & Actual distance & \multicolumn{2}{c}{ Initial distance } \\
\cline { 3 - 4 } & Value & Value & $1 \sigma$ \\
\hline Laurenti $\gamma$ & 800 & 1,100 & 200 \\
M40 & 800 & 1,100 & 200 \\
M41 & 550 & 850 & 200 \\
M37-i & 180 & 480 & 195 \\
M37-h & 65 & 370 & 190 \\
M37-a & 47 & 330 & 160 \\
M37-b & 18 & 120 & 55 \\
M37-c & 2 & 55 & 25 \\
Laurenti $\delta$ & 850 & 1,300 & 380 \\
M41 & 850 & 1,300 & 380 \\
M40 & 600 & 1,045 & 380 \\
M39 e & 200 & 655 & 370 \\
M39 d & 150 & 585 & 355 \\
M39 c & 100 & 500 & 300 \\
M39 b & 15 & 110 & 60 \\
M39 a & 5 & 70 & 25 \\
\hline Disances & & &
\end{tabular}

Distances are given in centimetre. Actually measured distances are smaller than the initial lengths due to the large loss of $\mathrm{CaO}$ and $\mathrm{CO}_{2}$ which is responsible for the volume loss occurred during skarn formation. Curve 3 represents the initial conditions. Curve 4 gives the case where the isotope alteration is prior to the volume loss. The curves are the resulting fit to each case, using program ISOFIT (personal communication Baumgartner, unpublished). The peclet number $N_{P e}$, does not change significantly, though infiltration and diffusion distances do. See text for further discussion

prior to volume loss, $\mathrm{O}$ alteration occurred over a greater distance than observed today. Nevertheless, Peclet numbers only show a slight increase when volume loss is accounted for: in $\gamma$, the Peclet number is about $9.1 \pm 2.0$ and, in $\delta$, it varies between $7.3 \pm 2.2$ and $8.1 \pm 1.8$. These results show, surprisingly, that the ratio of infiltration to diffusion is not strongly influenced by these calculations.

The most likely scenario is that stable isotope exchange and calcite loss were probably contemporaneous. This implies that the effective evolution will have been in between the two scenarios. Hence, distances of $\mathrm{O}$ alterations evolved during contact metamorphism and it is likely that $\mathrm{O}$ alterations could have occurred over greater distances than those observed today due to volume loss. If the $\mathrm{O}$ isotope alteration occurred prior to the volume loss (case ii and curve 4 in Fig. 10), this distance would have been about 2-3 times larger. This observation implies that fluid flows could be several times greater if volume losses are taking into account. Given that the Peclet number stayed roughly constant, this would also imply that diffusion was 2-3 times more important.

\section{Conclusions}

Chemical mass transfer during contact metamorphism has been quantified for a metacarbonate xenolith in the Quérigut massif (Pyrenees, France). Metacarbonates show a 
significant loss of modal calcite followed by the development of a thin exoskarn zone composed of diopside, garnet, wollastonite and clinozoisite close to the contact. Mass balance calculations show a large loss of the $\mathrm{CaO}$ (up to $90 \pm 3 \%$ ), $\mathrm{Sr}$ (up to $-85 \pm 18 \%$ ) and $\mathrm{CO}_{2}$ (up to $-97 \pm 3 \%$ ). The others elements, like $\mathrm{SiO}_{2}, \mathrm{Al}_{2} \mathrm{O}_{3}$, initially present in the limestone behave nearly immobile and are therefore passively concentrated. A small increase of $\mathrm{SiO}_{2}$, $\mathrm{Al}_{2} \mathrm{O}_{3}$ and $\mathrm{Fe}_{2} \mathrm{O}_{3}$ contents occurs in one of the profiles in the immediate vicinity of the contact. Thus, in this study, the skarn formation is characterized by the lack of large chemical element influx from the granitic protolith. This geochemical evolution is due to two different processes: (1) decarbonation reactions leading to calc-silicate minerals and release of $\mathrm{CO}_{2}$ and (2) stoichiometric "calcite" loss, with concurrent $\mathrm{CaO}$ and $\mathrm{CO}_{2}$ loss. A large volume decrease results from these processes: up to $86 \pm 6 \%$ of the initial volume is lost at the contact with the granitoid intrusions. This can strongly affect the interpretation of stable isotope profiles: isotope alteration distances could evolve during contact metamorphism and the isotope alteration could have occurred over a greater distance than those observed today. This study demonstrates that volume variations must be taken into account in mass transfer studies in contact aureoles where carbonates are involved. Furthermore, $\mathrm{CO}_{2}$ release is of importance for the mass budget of $\mathrm{CO}_{2}$. If these large amounts of $\mathrm{CO}_{2}$ are not trapped in the upper levels of the continental crust during their ascent, they also could lead to increase in atmospheric $\mathrm{CO}_{2}$ concentration depending on the volume amount of metacarbonates involved during the skarn formation processes, as proposed by Kerrick and Caldeira (1993) and Roselle and Baumgartner (1997).

Acknowledgments Substantial funding for this research was provided by the Bureau de Recherches Géologiques et Minières (B.R.G.M.). We would like to thank the C.A.M. (H. R. Pfeifer Laboratory) at the University of Lausanne for their analytic facilities and J. P. Sizun for density calculations at the University of FrancheComté. We would like to thank the two anonymous reviewers for their constructive remarks.

\section{References}

Abu El-Enen MM, Okrusch M, Will TM (2004) Contact metamorphism and metasomatism at a dolerite-limestone contact in the Gebel Yelleq area, Northern Sinai, Egypt. Mineral Petrol 81:135-164. doi:10.1007/s00710-004-0031-y

Ague JJ (1994) Mass transfer during Barrovian metamorphism of pelites, South-Central Connecticut I: evidence for changes in composition and volume. Am J Sci 294:989-1057

Ague JJ (2003) Fluid infiltration and transport of major, minor and trace elements during regional metamorphism of carbonate rocks, Wepawaug schist, Connecticut, USA. Am J Sci 303:753816. doi:10.2475/ajs.303.9.753

Aparicio M (1975) Métamorphisme et déformation au contact d'un massif plutonique: l'encaissant du complexe de Quérigut. Université Paul Sabatier, Toulouse, France, Thèse $3^{\text {ème }}$ cycle, pp 88
Aubry A (1999) Etude pétrologique, structurale et métamorphique de la bordure ouest du pluton de Quérigut (Ariège, France). Université de Neuchâtel. Neuchâtel, Switzerland, Diplôme, p 66

Barnolas A, Chiron JC (1996) Synthèse géologique et géophysique des Pyrénées. Vol 1: Introduction. Géophysique. Cycle hercynien. Editions BRGM-ITGE, pp 729

Baumgartner LP, Olsen SN (1995) A least-squares approach to mass transport calculations using the isocon method. Econ Geol 90:1261-1270

Baumgartner LP, Rumble D III (1988) Transport of stable isotopesdevelopment of continuum theory for stable isotope transport. Contrib Mineral Petrol 98:273-285. doi:10.1007/BF00372362

Baumgartner LP, Valley JW (2001) Stable isotope transport and contact metamorphic fluid flow. In: Stable isotope geochemistry. Mineralogical Society of America, Washington, DC. Rev Mineral Geochem 43:415-467. doi:10.2138/gsrmg.43.1.415

Bear J (1988) Dynamics of fluids in porous media. Dover, New York, p 764

Bowman JR, Willett SD (1991) Spatial patterns of oxygen isotope exchange during one-dimensional fluid infiltration. Geophys Res Lett 18:971-974. doi:10.1029/91GL01079

Brimhall GH, Dietrich WE (1987) Constitutive mass balance relations between chemical composition, volume, density, porosity, and strain in metasomatic hydrochemical systems: results on weathering and pedogenesis. Geochim Cosmochim Acta 51(3):567587. doi:10.1016/0016-7037(87)90070-6

Brown PE, Essene EJ (1985) Activity variations attending tungsten skarn formation, Pine Creek, California. Contrib Mineral Petrol 89:358-369. doi:10.1007/BF00381557

Buick IS, Cartwright I (2000) Stable isotope constraints on the mechanism of fluid flow during contact metamorphism around the Marulan Batholith, NSW, Australia. J Geochem Explor 6970:291-295. doi:10.1016/S0375-6742(00)00027-3

Buick IS, Cartwright I (2002) Fractured-controlled fluid flow and metasomatism in the contact aureole of the Marulan Batholith (New South Wales, Australia). Contrib Mineral Petrol 143:733-749

Cartwright I, Buick IS (2000) Millimetre-scale variation in metamorphic permeability of marbles during transient fluid flow: an example from the Reynolds Range, central Australia. Contrib Mineral Petrol 140(2):163-179. doi:10.1007/s004100000180

Cartwright I, Valley JW (1991) Steep oxygen-isotope gradients at marble-metagranite contacts in the northwest Adirondack Mountains, New York, USA: products of fluid-hosted diffusion. Earth Planet Sci Lett 107(1):148-163. doi:10.1016/0012-821X(91) 90051-I

Cartwright I, Buick IS, Mass R (1997) Fluid flow in marbles at Jervois, central Australia: oxygen isotope disequilibrium and zoning produced by decoupling of mineralogical and isotopic resetting. Contrib Mineral Petrol 128:335-351. doi:10.1007/ s004100050313

Cook SJ, Bowman JR (2000) Mineralogical evidence for fluid-rock interaction accompanying prograde contact metamorphism of siliceous dolomites: Alta Stock Aureole, Utah, USA. J Petrol 41(6):739-757. doi:10.1093/petrology/41.6.739

Cook SJ, Bowman JR, Forster CB (1997) Contact metamorphism surrounding the Alta stock: finite element model simulation of heat and ${ }^{18} \mathrm{O} /{ }^{16} \mathrm{O}$ mass-transport during prograde metamorphism. Am J Sci 297:1-55

Debon F, Enrique P, Autran A (1996) Magmatisme hercynien. In: Synthèse géologique et géophysique des Pyrénées, vol 1. Introduction. Géophysique. Cycle hercynien. Editions BRGMITGE, vol 1, pp 361-499

de Lummen G, Verkaeren J (1986) Physicochemical study of skarn formation in pelitic rock, Costabonne peak area, eastern Pyrenees, France. Contrib Mineral Petrol 93:77-88. doi:10.1007/ BF00963586 
Dipple GM, Ferry JM (1992) Fluid flow and stable isotopic alteration in rocks at elevated temperatures with applications to metamorphism. Geochim Cosmochim Acta 56(9):3539-3550. doi: 10.1016/0016-7037(92)90397-2

Durand C, Boulvais P, Marquer D, Rossy M (2006) Stable isotope transfer in open and closed system across chemically contrasted boundaries: example from metacarbonate-granitoid contacts in the Quérigut magmatic complex (Eastern Pyrénées, France). J Geol Soc London 163:827-836. doi:10.1144/0016-76492005-075

Einaudi MT, Burt DM (1982) A special issue devoted to skarn deposits. Introduction-terminology, classification and composition of skarn deposits. Econ Geol 77(4):745-754

Ferry JM (1982) A comparative geochemical study of pelitic schists and metamorphosed carbonate rocks from south-central Maine, USA. Contrib Mineral Petrol 80(1):59-72. doi:10.1007/ BF00376735

Ferry JM (1991) Dehydration and decarbonation reactions as a record of fluid infiltration. In: Contact metamorphism. Mineralogical Society of America. Rev Mineral 26:351-393

Ferry JM (1994) Role of fluid flow in the contact metamorphism of siliceous dolomitic limestones. Am Mineral 79:719-736

Ferry JM, Sorensen SS, Rumble D III (1998) Structurally controlled fluid flow during contact metamorphism in the Ritter Range pendant, California, USA. Contrib Mineral Petrol 130:358-378. doi:10.1007/s004100050371

Ferry JM, Wing BA, Penniston-Dorland SC, Rumble D (2002) The direction of fluid flow during contact metamorphism of siliceous carbonate rocks: new data for the Monzoni and Predazzo aureoles, northern Italy, and a global review. Contrib Mineral Petrol 142:679-699

Forester RW, Taylor HPJ (1977) ${ }^{18} \mathrm{O} /{ }^{16} \mathrm{O}, \mathrm{D} / \mathrm{H}$, and ${ }^{13} \mathrm{C} /{ }^{12} \mathrm{C}$ studies of the tertiary igneous complex of Skye, Scotland. Am J Sci 277:136-177

Gerdes ML, Valley JW (1994) Fluid flow and mass transport at the Valentine wollastonite deposit, Adirondak Mountains, New York State. J Metamorph Geol 12:589-608. doi:10.1111/j.15251314.1994.tb00045.x

Gieré R (1990) Hydrothermal mobility of Ti, Zr and REE: examples from the Bergell and Adamello contact aureoles (Italy). Terra Nova 2:60-67. doi:10.1111/j.1365-3121.1990.tb00037.x

Grant JA (1986) The isocon diagram-a simple solution to Gresens'equation for metasomatic alteration. Econ Geol 81:1976-1982

Gresens RL (1967) Composition-volume relationships of metasomatism. Chem Geol 2:47-65. doi:10.1016/0009-2541(67)90004-6

Guitard G, Vielzeuf D, Martinez F (1996) Métamorphisme hercynien. In: Synthèse géologique et géophysique des Pyrénées, vol 1. Introduction. Géophysique. Cycle hercynien. Editions BRGMITGE, vol 1, pp 501-584

Harris NB, Einaudi MT (1982) Skarn deposits in the Yerington District, Nevada: Metasomatic skarn evolution near ludwig. Econ Geol 77:877-898

Kerrick DM, Caldeira K (1993) Paleoatmospheric consequences of $\mathrm{CO}_{2}$ released during early cenozoic regional metamorphism in the trthyan orogen. Chem Geol 108:201-230. doi:10.1016/00092541(93)90325-D

Leterrier J (1972) Etude pétrographique et géochimique du massif de Quérigut (Ariège), France. Université Nancy I, Nancy, France, Thèse $3^{\text {ème }}$ cycle, pp 292

Marquardt DW (1963) An algorithm for least-squares estimations of nonlinear parameters. J Soc Ind Appl Math 11(2):431-441. doi: $10.1137 / 0111030$

Marre J (1973) Le complexe éruptif de Quérigut: Pétrologie, structurologie, cinématique de mise en place. Université Paul Sabatier, Toulouse, France, Thèse $3^{\text {ème }}$ cycle, pp 536
Nabelek PI (1991) Stable isotope monitors. In: Contact metamorphism. Mineralogical Society of America. Rev Mineral 26:395435

Nabelek PI, Labotka TC (1993) Implications of geochemical fronts in the Notch Peak contact-metamorphic aureole, Utah, USA. Earth Planet Sci Lett 119:539-559. doi:10.1016/0012-821X(93) 90061-D

Nabelek PI, Labotka TC, O’Neil JR, Papike JJ (1984) Contrasting fluid/rock interaction between the Notch Peak granitic intrusion and argillites and limestones in western Utah: evidence from stable isotopes and phase assemblages. Contrib Mineral Petrol 86:25-34. doi:10.1007/BF00373708

Nagy KL, Parmentier EM (1982) Oxygen isotopic exchange at an igneous intrusive contact. Earth Planet Sci Lett 59(1):1-10. doi: 10.1016/0012-821X(82)90111-X

Potdevin J-L, Marquer D (1987) Méthodes de quantification des transferts de matière par les fluides dans les roches métamorphiques déformées. Geodin Acta 1(3):193-206

Roberts MP, Pin C, Clemens JD, Paquette J-L (2000) Petrogenesis of mafic to felsic plutonic rock associations: the calc-alcaline Quérigut complex, French Pyrenees. J Petrol 41(6):809-844. doi: 10.1093/petrology/41.6.809

Rollinson HR (1993) Using geochemical data: evaluation presentation interpretation. Longman Group, London, p 352

Roselle GT, Baumgartner LP (1997) Estimating $\mathrm{CO}_{2}$ production by contact metamorphism of siliceous carbonates; Ubehebe Peak, California. Abstr Program Geol Soc Am 29(6):92

Roselle GT, Baumgartner LP, Valley JW (1999) Stable isotope evidence of heteregeneous fluid infiltration at the Ubehebe Peak Contact Aureole, Death Valley National Park, California. Am J Sci 299(2):93-138

Rumble D, Ferry JM, Hoering TC, Boucot AJ (1982) Fluid flow during metamorphism at the Beaver Brook fossile locality, New Hampshire. Am J Sci 282:886-919

Spear FS (1995) The metamorphism of siliceous dolomites (calcsilicates). In: Metamorphic phase equilibria and pressuretemperature-time paths. Mineralogical Society of America, pp 447-467

Takeno N (1994) Contribution à l'étude des skarns du massif de Quérigut (Pyrénées Orientales, France): géochimie des éléments traces et modélisation des transferts de matière. Ecole Nationale Supérieure des Mines de Saint-Etienne, Ecole Nationale Supérieure des Mines de Paris, France, Thèse $3^{\text {ème }}$ cycle, pp 261

Taylor BE, O'Neil JR (1977) Stable isotope studies of metasomatic $\mathrm{Ca}-\mathrm{Fe}-\mathrm{Al}-\mathrm{Si}$ skarns and associated metamorphic and igneous rocks, Osgood Mountains, Nevada. Contrib Mineral Petrol 63:149. doi:10.1007/BF00371674

Thompson JBJ (1959) Local equilibrium in metasomatic process. In: Abelson PH (ed) Researches in geochemistry, vol 1. Wiley, New York, pp 427-457

Toulhoat $\mathrm{P}$ (1982) Pétrographie et géochimie des isotopes stables $\left(\mathrm{D} / \mathrm{H},{ }^{18} \mathrm{O} /{ }^{16} 0,{ }^{13} \mathrm{C} /{ }^{12} \mathrm{C},{ }^{34} \mathrm{~S} /{ }^{32} \mathrm{~S}\right)$ des skarns du Quérigut, comparaison avec les skarns à scheelite des Pyrénées. Université Pierre et Marie Curie, Paris 6, Paris, France, Thèse $3^{\text {ème }}$ cycle, pp 268

Tracy RJ, Rye DM, Hewitt DA, Schiffries CM (1983) Petrologic and stable-isotopic studies of fluid-rock interactions, south-central Connecticut: I. The role of infiltration in producing reaction assemblages in impure marbles. Am J Sci 283-A:589-616

Turner DR, Bowman JR (1993) Origin and evolution of skarn fluids, Empire zinc skarns, Central Mining District, New Mexico, USA. Appl Geochem 8(1):9-36. doi:10.1016/0883-2927(93)90054-K

Valley JW (1986) Stable isotope geochemistry of metamorphic rocks In: Stable isotopes in high temperature geological processes. Mineralogical Society of America. Rev Mineral 16:445-489 